\title{
When greens see red
}

\section{An environmental warning and call to curb consumerism.}

\section{Red Sky At Morning: America and the Crisis of the Global Environment \\ by James Gustave Speth \\ Yale University Press: 2004. 304 pp. \\ $\$ 24, £ 15.99$}

\section{Dick Taverne}

James Speth is not someone whose warnings that our planet's environment is rapidly deteriorating can be lightly dismissed. He is a former administrator of the United Nations Development Programme, was an adviser on environmental matters to US presidents Jimmy Carter and Bill Clinton, and was a founder of the World Resources Institute, a valuable source of information about the environment. He is not an ecofundamentalist blind to any developments that do not suit his case.

In Red Sky at Morning he concedes, for example, that in countries of the Organisation for Economic Co-operation and Development, the discharge of chemical waste and sewage into waterways, human exposure to lead, and emissions of sulphur dioxides and particulates have all declined. What's more, he admits that the ozone layer could recover by the middle of this century and that multinational companies often have a better environmental record than their local counterparts. Indeed, he even says that a move away from carbon-intensive fuels may have to include a shift to nuclear power, both fission and fusion (although in a footnote he rather discounts its feasibility).

Although there are flashes of optimism, they are occasional patches of blue in a darkening sky. On the whole, Speth's theme echoes those of the classical prophets of doom: Paul Ehrlich, Barry Commoner, The Limits to Growth by Donella Meadows and others, Lester Brown and the Worldwatch Institute, all of whom he quotes with approval. Most of the mantras of green activists are repeated in the pages of his book: the threat to our health from dioxins and pesticides, DDT and endocrine disrupters, and probably, he implies, from genetically modified crops. He extols the virtues of organic farming, stresses the importance of the precautionary principle, and uncritically assumes that globalization damages our environment and increases poverty and inequality.

Speth lists ten principal concerns, most of which are shared by pragmatic environmentalists: the hole in the ozone layer; climate change; the loss of agricultural land; the depletion of tropical forests; the mass extinction of species; population growth; mismanagement of freshwater resources; overfishing

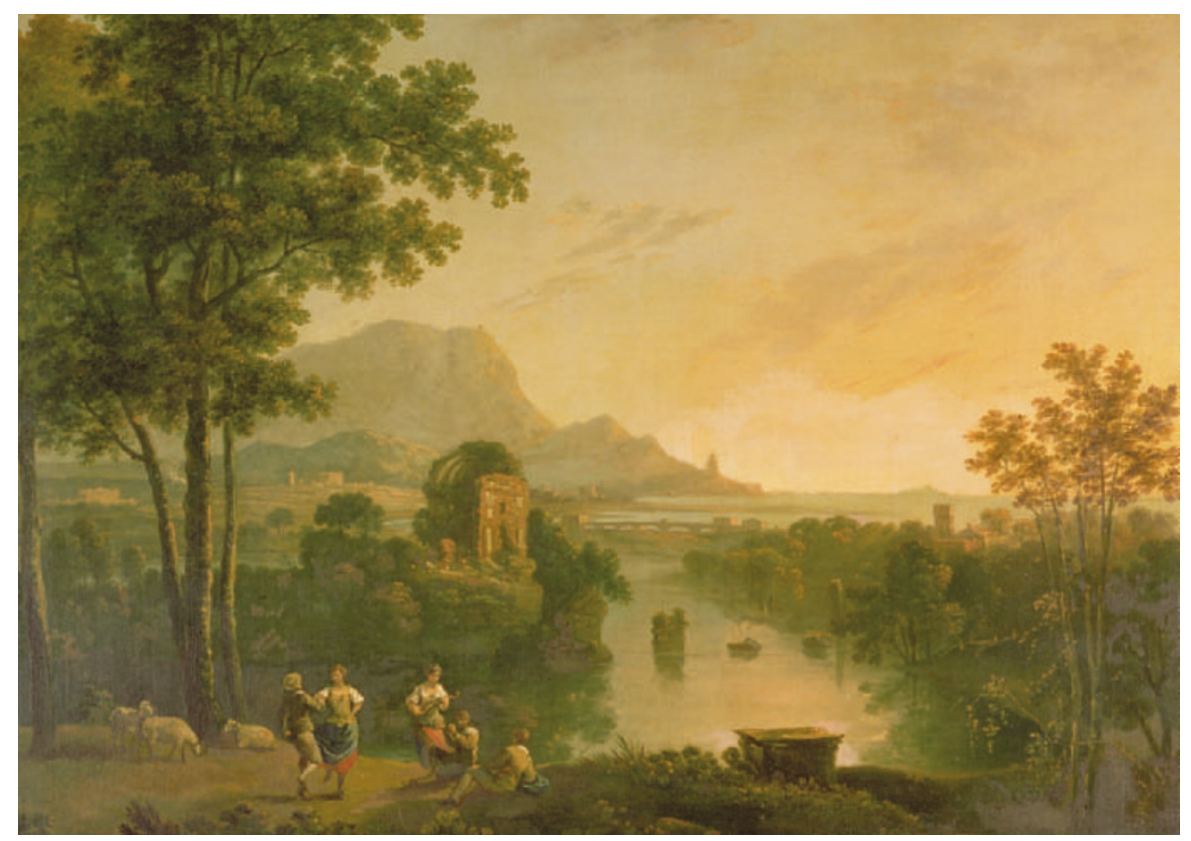

A false picture? Richard Wilson's painting conjures up a rural idyll, but life was never really like this.

and marine pollution; mismanagement of pesticides and organic pollutants; and acid rain and other atmospheric pollutants. Unfortunately, the reaction of governments has been a problem-defined approach, he argues, whereas the underlying causes of the deterioration are consumerism and economic growth. Our fundamental error, he says, is to take an anthropocentric view of the world, to think that "nature belongs to us, not we to nature". Some of Speth's proposed remedies are sensible, but others include unquestioning support for green non-governmental organizations and for the World Social Forum at Porto Alegre in Brazil, the main theme of which is unqualified opposition to capitalism. "It is time," he declares, "for we, the people, as citizens and as consumers, to take charge."

It is perhaps surprising to find a man with Speth's record resurrecting the doctrine of the doomsters of the 1970s: that we will soon exhaust Earth's limited resources. Such forecasts have proved wildly inaccurate. The Limits to Growth predicted that we would run out of gold, zinc, mercury and oil before 1992. In 1981, Ehrlich forecast that half of the world's species would be extinct by 2000 and all would be gone by 2010-25. He also wrote, in The Population Bomb in 1968: "The battle to feed humanity is over. In the course of the 1970 s the world will experience starvation of tragic proportions - hundreds of millions of people will starve to death."

Remedies prescribed by doctors who continually misdiagnose diseases should not be swallowed uncritically. Speth shows as little regard for contemporary evidence as he does for the reliability of previous forecasts of doom. To promote organic farming as he suggests, using a system with much lower crop yields than other farming methods, would aggravate the shortage of good farming land. He repeats common misconceptions about the harmful effects of the pesticide DDT on human health, which have never been proved. He ignores the fact that, according to the World Health Organization, DDT has prevented more than 50 million deaths from malaria, and that the ban on its use in most countries, even for spraying the inside walls of houses, still results in millions of avoidable deaths.

Leaving aside oversimplified and exaggerated assumptions about the harm to humans caused by chemicals such as dioxins, endocrine disrupters and pesticides, the basic argument of Red Sky at Morning is that humans are destroying nature's capital hence its obsession with limits. This reflects a widely held view in environmentalist circles that the Enlightenment was a disaster because, following Bacon and the birth of modern science, we have sought to control nature, causing its destruction. Speth seems to assume that the pre-Enlightenment era was a kind of blissful Arcadia in which happy peasants lived in harmony with nature, since destroyed by science and technology. In fact it was a time when life was nasty, brutish and short, not least because medieval, pre-scientific superstition could not control cholera, 
pestilence and the ravages of any number of diseases that modern medicine, by controlling nature, can prevent or treat. In prescientific agrarian society, life was a perpetual struggle in which the scarcity of resources led to a hierarchical, authoritarian form of organization in which most people suffered or prospered according to prescribed rank.

Indeed it is precisely because humanity has learnt to control some aspects of nature that civilization has advanced. Economic growth is the child of science and technology. To cry "Enough is enough", as Speth would have us do, would be to abandon any hope of substantially diminishing poverty, hunger and disease in the world. Without the contribution of science and technology, the task of preserving and enhancing the quality of life on our planet would be impossible. Speth raises serious issues, but they deserve a more balanced treatment than the prescriptions in his book.

Dick Taverne is chairman of the charity Sense

About Science, 60 Cambridge Street,

London SW1V 4QQ, UK.

\section{Crossing the boundary}

\section{Biological Physics: Energy, Information, Life \\ by Philip Nelson \\ W. H. Freeman: 2004.600 pp. $£ 34.99, \$ 106.50$ \\ Christopher M. Dobson}

"Physics is what physicists do." This definition, which is current in at least some physics departments, is not intended (we trust) simply to confuse the rest of the scientific community. Rather, it suggests that the discipline of physics, more conventionally defined (in the Shorter Oxford English Dictionary) as the branch of science "that deals with the nature and properties of matter and energy", can be brought to bear on a wide range of problems across the broad spectrum of human knowledge.

Indeed, 100 years ago, physicists brought about a revolution in chemistry, when the discovery of the electron led to an understanding of the nature of atoms and of molecular structure and bonding. And 50 years ago, physicists ushered in a revolution in biology, with dramatic demonstrations that $\mathrm{X}$-ray diffraction could reveal the structures of DNA and proteins. Nevertheless, relatively few physicists have been "doing biology", and many of these migrated from mainstream physics departments to set up enterprises such as the Laboratory of Molecular Biology in Cambridge, UK, or the Institute of Protein Research in Puschino, Russia.

But times are changing. Physicists in physics departments are now increasingly

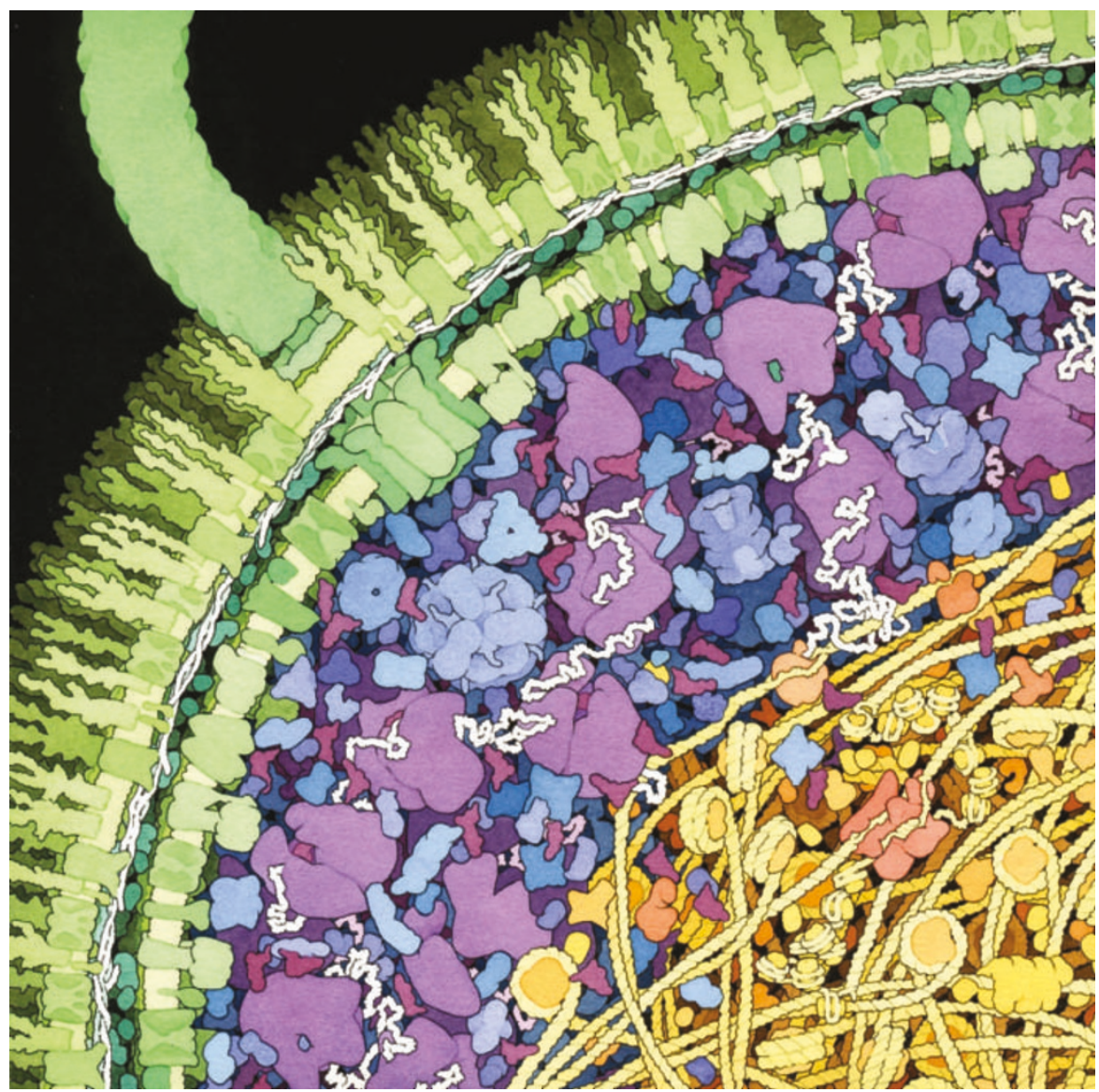

Living colour: David Goodsell's 'crowded cell' image of the bacterium Escherichia coli.

looking around for grand challenges to rival those that led to major advances in our understanding of many aspects of the physical world, from the fundamental particles of matter to the origins of the Universe. And biology, the study of the nature of life itself, is not short of such challenging problems. Some of these are likely to succumb to bigger and better physical techniques; others might well be revolutionized by the reductionist approach so favoured by physicists to identify and tease out fundamental principles from the vast arrays of data that such techniques can generate.

If such grand challenges are to be tackled successfully, however, it is crucial that physicists collaborate with biologists, and with those in other disciplines, including chemistry, mathematics and medicine. For such collaborations to work, there has to be a common language and an appreciation of the strengths and weaknesses of each other's abilities.

Philip Nelson's excellent text, Biological Physics, provides material for the types of course we should now be offering to all our students. Nelson says that his book is for "life science students who are willing to use calculus" and for "physical science and engineering students who are willing to think about cells". And indeed, his book should educate and intrigue both groups. Particularly impressive is the subtle way that topics that often cause the eyes of even the most diligent student to glaze over are made to seem not just interesting to read about but compelling to learn. Statistical mechanics and thermodynamics are obvious examples, and key concepts such as the Boltzmann distribution and free energy are introduced to explain such questions as why "cells do not work best at the coldest temperatures", despite the fact that life is about generating highly ordered structures. Moreover, although much emphasis is placed on understanding ideas, the text does not allow anyone to forget that some real equations need to be mastered if such an understanding is to be satisfying and widely applicable.

Another good aspect of this book is that it is right up to date in the topics and examples that it covers. Many relatively recent ideas, such as the use of free-energy surfaces for understanding protein folding and of optical tweezers for probing muscle action, are covered in depth, with at least some references to the original literature. There are frequent comments about the way that modern ideas and techniques have emerged. As Nelson cleverly shows, many of the most important scientific breakthroughs have come about unexpectedly through just the type of interdisciplinary studies that this book promotes.

For example, it was the renowned physicist Robert Hooke who realized in the midseventeenth century, after peering down a microscope that he himself had constructed, 